\section{University of Birmingham: Appointments}

THe following announcements have been recently made in the Ufiversity of Birmingham. The title of reader in astrophysics has been conferred on Dr. M. C. Johyson, lecturer in physics. Appointments: Prof. F. W. Shotton, of Sheffield, to the chair of geology in succession to Prof. L. J. Wills; W. I. B. Smith, to be Nuffield Foundation Fellow in the Dedartment of Physics; Dr. D. H. Whiffen, to be lecturer in physical chemistry; W. R. Cheetham, to be lecturer in mining; J. G. Jackson, to be lecturer in pathology; Miss V. Norris, research fellow in the Lepartment of Medical Statistics, to be senior statistical officer. Resignations : Dr. C. H. Westcott, Nuffield Research Fellow, on appointment as associate professor in the Department of Physics, MeGill University; and Dr. R. Padley, senior statistical officer in the Department of Medical Statistics, on appointment as deputy statistical officer to the City of Birmingham Corporation. G. de Q. Robin, lecturer in physics, has been given leave of absence to join the Anglo-Norwegian expedition to Queen Maud Land. G. T. Warwick is leading an expedition to Lyngen Fjord, Northern Norway, this summer ; the party will consist of seven final-year geography students and a Norwegian student from the Civil Engineering Department. The objects of the expedition will be to make a study of the geomorphology, human geography and microclimatology of the region. H. Thorpe is visiting Denmark and Sweden during the summer vacation to continue research into forms of rural settlement, with particular reference to Green Villages.

\section{University of Leeds: Appointments}

THE following appointments have recently been made in the Univerglty of Leeds: Mr. W. R. Atkin, to succeed Prof. D. McCandlish, who retires at the end of the pregent session, in the chair of leather industries; A. S. Carson, to be lecturer in inorganic and physica chemistry; Dr. N. J. Petch, to be reader in hetallurgy; W. K. J. Walls, to be lecturer in anat my. An offer by Messrs. Bolton Leathers, Ltd., to establish a postgraduate fellowship in the Leather Industries Department, to the value of $£ 450-£ 600$ a year for a period of three years in the first instance, has been accepted; the award will be known as "The Boltonia Fellowship".

\section{Conference on Amino-Acid and Protein Hydro- lysates}

THe Food Group of the Society of Chemical Industry is arranging a conference on "Amino Acids and Protein Hy/rolysates", which will be held in the William Heveridge Hall, University of London, Senate house, London, W.C.1, during September 28-30. Papers will be presented upon the chemistry, propfrties, preparation, analysis, industrial applicat lons and nutritive aspects of amino-acids and protein hydrolysates, and it is hoped that visits may be arranged to laboratories engaged upon work in this field. A detailed programme and application forms for registration will be issued in due course; the honorary secretary of the conference is Dr. A. J. Amos, 88 Madeley Road, London, W.5.

\section{Second International Biometric Confererce}

TнE Sefond International Biometric Conference will be held in the University of Geneva during August 30-September 2, under the auspices of the
Biometric Society. Aspects of biometry which will be considered in the scientific sessions include recent applications in genetics, teaching and education, experimental design, the present status of the science, industrial applications and biological assay. The Conference will close with a session of contributed papers. Further information and reservations are obtainable through the secretary of the Conference Committee, Prof. Arthur Linder, 24 Avenue de Champel, Geneva, Switzerland.

The Night Sky in July

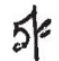

Fulc mgon occurs pnstily 10d. 07h. 4Im., U.т., and new Afton on July 2 d. 19h. 33m. The following conjunct pns with the moon take place: July IId.

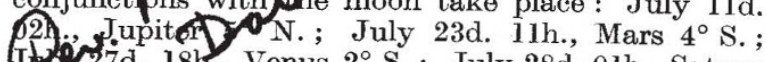
J 27 d. 1811., Venus $2^{\circ}$ S. ; July 28d. 01h., Saturn 6. $\mathrm{S}$. In addition to these conjunetions with the moon, Venus is in conjunction with Saturn on July 31 d. $06 \mathrm{~h}$., Venus $0 \cdot 2^{\circ} \mathrm{S}$. Mercury rises an hour before the sun during the first half of the month and later on becomes an evening star, but sets too soon after sunset to be visible. Venus sets more than an hour after the sun on July 1 and 31 , and can be seen as an evening star throughout the month; about nine-tenths of the illuminated disk is visible during July. Mars is a morning star, rising at $2 \mathrm{~h}$. $10 \mathrm{~m}$., 1h. $50 \mathrm{~m}$. and $1 \mathrm{~h} .33 \mathrm{~m}$. at the beginning, middle and end of the month, respectively. The planet is fairly close to $\zeta$ Tauri towards the middle of the month. Jupiter, in the constellation of Sagittarius, rises in the early night hours and can be observed low down in the heavens; but as the planet does not attain an altitude greater than $18^{\circ}$ in the latitude of Greenwich, it is not favourably placed for observation in higher northern latitudes. It is in opposition to the sun on July 20. Saturn, in the constellation of Leo, is visible during the early portion of the night, setting at $22 \mathrm{~h}$. $45 \mathrm{~m}$. and $20 \mathrm{~h} .52 \mathrm{~m}$. at the beginning and end of the month, respectively. Occultations of stars brighter than magnitude 6 are as follows: July $6 \mathrm{~d}$. 22h. 44.7m., 40B. Scor. $(D)$; July 21d. 01h. $17 \cdot 4 \mathrm{~m}$., 133B. Taur. $(R)$. $D$ and $R$ refer to disappearance and reappearance, respectively, and the latitude of Greenwich is assumed. The earth enters aphelion on July 2.

\section{Announcemepts}

DR. S. C/ HaRLAND, F.R.S., since 1939 director of the Instipute of Cotton Genetics, National Agricultural Socief, Peru, has been appointed reader in genetics in the University of Manchester.

DR. REgIy CD CHILD has relinquished the post of director of the Coconut Research Scheme, Ceylon, which ho has held since 1932. He will be succeeded by 2. F. C. Cooke, who was chemist (coconut products) with the Department of Agriculture, Malaya, during 1929-38, and canning officer of the same Department during 1946-49.

Followrng upon Prof. Niels Bohr's Gifford Lectures, to be delivered in Edinburgh during October 21-Novenher 11, a conference on elementary particles will be held in the Department of Natural Philosophy, University of Edinburgh, during November 14-16. Further information will be available about the end of August and can be obtained from Mr. A. Nisbet, Department of Mathematical Physics, University of Edinburgh, Drummond Street, Edinburgh \& 